\title{
IMPLEMENTATION OF A METHOD TO DETERMINE LOLITREM-B IN RYEGRASS (Lolium perenne L.) BY LIQUID CHROMATOGRAPHY (HPLC)
}

\author{
Stella Moyano A. ${ }^{1 *}$, Francisco Lanuza A. ${ }^{2}$, Alfredo Torres B. ${ }^{2}$, Ernesto Cisternas A. ${ }^{2}$, and \\ Marcela Fuentes V. ${ }^{1}$
}

\begin{abstract}
Lolitrem-B is a neurotoxic substance that causes the ryegrass staggers syndrome in cattle, sheep, and horses consuming ryegrass (Lolium perenne L.) infected with endophytic fungus Neotyphodium lolii (Latch, Christensen, and Samuels) Glenn, Bacon, and Hanlin. Due to the increasing use of ryegrass pasture in southern Chile, it is necessary to know the content of lolitrem-B to optimize grazing management and reduce the effect on animal health. The objective of this study was to implement a method to determine lolitrem-B in ryegrass. Ryegrass samples were used without the endophyte, freeze-dried, and kept in darkness at $-18{ }^{\circ} \mathrm{C}$ to establish the method. Then, a pure lolitrem-B standard was added and the toxin was extracted with a mixture of chloroform-methanol (2:1), purified in manually prepared silica gel 60 columns. Five standard addition levels were studied $(0.05,0.10,0.30,0.60$, and 1.00 $\mathrm{mg} \mathrm{kg}^{-1}$ ) with five replicates per level. The recovery was 96.6 to $99.9 \%$, on average and the coefficient of variation (CV) ranged between 0.9 and $5.9 \%$. Quantification was done by high-performance liquid chromatography (HPLC) and fluorescence detection. The quantification limit was $0.05 \mathrm{mg} \mathrm{kg}^{-1}$. This method of determining neurotoxin lolitrem-B in ryegrass samples was implemented for the first time in Chile. It is fast and inexpensive; it has good precision, accuracy and repeatability.
\end{abstract}

Key words: mycotoxin, neurotoxin, endophyte fungi, Neotyphodium lolii.

\section{INTRODUCTION}

The incorporation of perennial ryegrass with endophytic fungus Neotyphodium lolii (Latch, Christensen and Samuels) Glenn, Bacon, and Hanlin (previously called Acremonium lolii) in pasture of southern Chile, as a response to the attack of the Argentine stem weevil (Listronotus bonariensis Kuschel) (Lanuza et al., 2003a). Among the different toxins that $N$. lolii produces, peramine acts as the main repellent compound of the insect $L$. bonariensis, on the other hand lolitrem and ergovaline produce intoxication in mammals (Gallagher et al., 1981; Rowan, 1993; Porter, 1995).

In the lolitrem group, lolitrem-B is considered as the most important for livestock, being mainly responsible for the ryegrass staggers syndrome or ryegrass tremor (Gallagher et al., 1981; 1984; 1985; Porter, 1995).

\footnotetext{
Instituto de Investigaciones Agropecuarias, Centro Regional de Investigación La Platina, Casilla 439, Correo 3, Santiago, Chile. *Corresponding author (smoyano@inia.cl).

${ }^{2}$ Instituto de Investigaciones Agropecuarias, Centro Regional de Investigación Remehue, Casilla 24-0, Osorno, Chile.

Received: 11 December 2007.

Accepted: 30 May 2008
}

This intoxication affects bovines, sheep, and equines that grazed ryegrass pasture infected with the fungus, a neuromuscular alteration becoming apparent with tremors and variable degrees of hypersensibility to external stimuli, uncoordinated movements, rigidity in walking, and ataxia (Siegel et al., 1987; Blood et al., 1992; Rowan, 1993; Lanuza et al., 2003b). Also mentioned is the fact that it can affect animal production (Lanuza et al., 2003a).

The concentration of lolitrem-B varies according to climatic conditions (Oldenburg, 1997), plant tissues (Keogh and Tapper, 1993; Ball et al., 1995; 1997; Keogh et al., 1996), $\mathrm{N}$ soil content (Lane et al., 1997), and solar radiation (Fletcher et al., 2001). Keogh et al. (1996) state that the greatest endophyte and toxin concentrations are found in the lower parts of the plant, in the old leaves, and in senescent material, as well as in the seeds of the ear.

Bearing in mind that the pest $L$. bonariensis is found in New Zealand, all the seeds of the new perennial ryegrass varieties contain the endophyte fungus. Therefore, since Chile imports perennial ryegrass mostly from this country, it is necessary to adequately manage this technology. This occurs by knowing the endophyte level contained in the seeds and the toxin levels, such as lolitrem-B contained in 
the plants and plant parts throughout the year. This would allow carrying out adequate management of pasture use and cutting, with the objective of optimizing forage production and decreasing the risk of animal intoxication (Lanuza et al., 2003a). It is therefore relevant to develop a quantitative method that allows evaluating lolitrem-B in the prairies of southern Chile.

The isolation of lolitrem-B has been described in plant tissues and its identification by mass spectrometry and nuclear magnetic resonance spectroscopy (Gallagher et al., 1981; Miles et al., 1994). Its structure was determined by Gallagher et al. (1984). Grancher et al. (2004) describe a new method to obtain and purify lolitrem-B by countercurrent chromatography, achieving $96 \%$ purity. To determine it, extraction methods with solvents have been described and subsequent quantification by high-performance liquid chromatography (HPLC), with ultraviolet and fluorescence detector (Gallagher et al., 1985; Siegel et al., 1990; Barker et al., 1993; Hovermale and Craig, 2001).

The objective of this study was to develop a lowcost and low solvent consumption analytical method to determine lolitrem-B in ryegrass samples and its quantification by HPLC with fluorescence detector.

\section{MATERIALS AND METHODS}

This method is a modification of the one described by Gallagher et al. (1985), carried out during 2002 in the Laboratorio de Residuos de Pesticidas del Centro Regional de Investigación La Platina, Instituto de Investigaciones Agropecuarias (INIA). The samples to establish the method were complete perennial ryegrass plants without endophyte, cut at ground level, sent frozen and in the absence of light from the INIA Centro Regional de Investigación Remehue, Osorno, Los Lagos Region, to the Laboratorio de Residuos de Pesticidas, INIA La Platina, Santiago, Metropolitan Region.

\section{Preparation of lolitrem-B standard}

All the used reagents were suitable for residue analyses. The lolitrem-B standard was provided by AgResearch (Hamilton, New Zealand), $1 \mu \mathrm{g}$ toxin contained in amber-colored glass vials $(2 \mathrm{~mL})$. To the pure standard $(1 \mu \mathrm{g}), 500 \mu \mathrm{L}$ of dichloromethane were added, agitated in agitator tubes (Barnstead/Thermolyne, Dubuque, Iowa, USA), and divided in five portions of 100 $\mu \mathrm{L}$ in amber-colored vials. The solvent was evaporated with a nitrogen current under an extractor hood, the vials were kept in a dryer at $-18{ }^{\circ} \mathrm{C}$, and the residual contained in each vial $(0.2 \mu \mathrm{g}$ of lolitrem-B) was reconstituted with $1 \mathrm{~mL}$ of the same solvent. With this diluted standard, the curve was prepared and the additions to the ryegrass sample without endophyte were done.

\section{Method tests}

Sample preparation for assay. The frozen perennial ryegrass samples sent from Osorno were cut into pieces and homogenized by taking a portion of approximately $40 \mathrm{~g}$, then freeze-dried (freeze dryer Freezone 18, Labconco, Kansas City, Missouri, USA) maintaining the freeze dryer flasks in darkness, ground with a 60-mesh sieve, and kept in the dryer at $-18{ }^{\circ} \mathrm{C}$.

Diverse consecutive tests were done to optimize and obtain the method. Sample extraction used ratios of $1: 15$ and 1:20 of sample:solvent (chloroform-methanol $2: 1 \mathrm{v} / \mathrm{v}$ ), and agitation compared the extraction obtained with an orbital agitator (Cole Palmer, Roto-Torque, USA) versus an agitator with horizontal agitation (Gerhardt, Hamburg, Germany). For evaporation, to reduce costs, the use of nitrogen versus air in purification was compared, and since it was not indicated in the methods, different quantities of silica gel 60 were studied (0.04-0.063 $\mathrm{mm}$ ) for column chromatography (Merck, Darmstadt, Germany), activated at $180^{\circ} \mathrm{C}$ for $12 \mathrm{~h}$, adding 200,300 , and $500 \mathrm{mg}$ in the columns, as well as 100 and $500 \mathrm{mg}$ silica Sep-Pak cartridge (J.T. Baker, Phillipsburg, New Jersey, USA), with a vacuum chamber for the solid phase extraction (SPE) (J.T. Baker, Phillipsburg, New Jersey, USA).

\section{Method description}

For the recovery study carried out in five standard addition levels $\left(0.05,0.10,0.30,0.60\right.$, and $\left.1.00 \mathrm{mg} \mathrm{kg}^{-1}\right)$, a $0.1 \mathrm{~g}$ freeze-dried sample was weighed from $10-\mathrm{cm}$ test tubes with screw tops, protected from the light, six tubes for each level of addition. Diluted lolitrem-B standard was added to five tubes, a sixth was the control without standard addition, and another without a sample was the blank reaction tube. The following procedure was applied to each tube.

Extraction: $0.1 \mathrm{~g}$ of freeze-dried ground sample was extracted with $2 \mathrm{~mL}$ of a chloroform:methanol mixture $(2: 1 \mathrm{v} / \mathrm{v})$, agitated $1 \mathrm{~h}$ with horizontal agitation, left to rest $20 \mathrm{~min}$, an aliquot of $0.5 \mathrm{~mL}$ was taken and evaporated with nitrogen current until dry.

\section{Purification or clean up}

Preparation of columns for clean-up. Some $3 \mathrm{~mL}$ polypropylene syringes were used, a $9 \mathrm{~mm}$ diameter paper filter (Whatman 41, Maidstone, England) was put at the bottom of the syringe, plus $0.3 \mathrm{~g}$ silica gel $60(0.04-0.063$ $\mathrm{mm}$ ) for column chromatography (Merck, Darmstadt, Germany), activated at $180{ }^{\circ} \mathrm{C}$ for $12 \mathrm{~h}$, taking the precaution to not compact the silica, then a filter, and over it $0.5 \mathrm{~g}$ of anhydrous sodium sulphate (Merck, Darmstadt, Germany), plus another filter. 
The extraction residue was reconstituted with $1.5 \mathrm{~mL}$ of dichloromethane, agitated with a tube agitator, put through the purification column with the vacuum chamber for solid phase extraction (SPE), $1 \mathrm{~mL}$ dichloromethaneacetonitrile $(8: 2 \mathrm{v} / \mathrm{v})$ was added, eluding solvents were rejected, and lolitrem-B was finally eluded with $3 \mathrm{~mL}$ dichloromethane-acetonitrile $(8: 2 \mathrm{v} / \mathrm{v})$, resulting in a 5 $\mathrm{mL}$ volume flask capacity with the solvent mixture.

Sample extracts were filtered with Durapore, type GVWP $0.22 \mu \mathrm{m}$ and $25 \mathrm{~mm}$ diameter membranes (Millipore, Belford, Massachusetts, USA), and kept at $-18^{\circ} \mathrm{C}$, in ambercolored Eppendorf tubes until quantification.

\section{Chromatography}

We used HPLC (Merck-Hitachi, Tokyo, Japan), with an L-6200 pump, L-6000 interface, and L-7480 fluorescence detector. Wavelengths applied in the detector were: excitation $\left(\lambda_{\text {ex }}\right) 268 \mathrm{~nm}$ and emission $\left(\lambda_{\mathrm{em}}\right) 440$ $\mathrm{nm}$, injection valve Rheodyne 7125 (USA) with $20 \mu \mathrm{L}$ loop. Equipment used was the integration system of Chromatography Data Station Software (HPLC System Manager, Merck-Hitachi, Tokyo, Japan), plus a computer and printer.

The HPLC column chromatography used was silica $5 \mu \mathrm{m}$ Spherisorb, 4.6 and $250 \mathrm{~mm}$ (Waters Corporation, Wexford, Ireland), the mobile phase: dichloromethane:acetonitrile $(8: 2 \mathrm{v} / \mathrm{v})$, vacuum-filtered by Durapore, type GVWP $0.22 \mu \mathrm{m}$ and $47 \mathrm{~mm}$ diameter membranes (Millipore, Belford, Massachusetts, USA), degasified in an ultrasonic bath (Bransonic, Branson Ultrasonic Corporation, Danbury, USA) isocratic system with a $1.8 \mathrm{~mL} \mathrm{~min}^{-1}$ flow. Lolitrem-B retention time was $2.7 \mathrm{~min}$.

Due to the toxicity of lolitrem-B, precaution was taken to collect the eluding solvent from the chromatograph in a bottle under the solvent extractor hood.

\section{RESULTS AND DISCUSSION}

The most adequate sample/solvent ratio was 1:20 for the great volume of freeze-dried sample, differing from work by Gallagher et al. (1985) who used a 1:15 ratio. These authors worked with a $1 \mathrm{~g}$ dry sample at $45^{\circ} \mathrm{C}$ and $15 \mathrm{~mL}$ solvent, whereas in our method, we worked with only a $0.1 \mathrm{~g}$ freeze-dried sample and $2 \mathrm{~mL}$ solvent.

Recovery percentages $(\% \mathrm{R})$ were similar $(>90 \%)$ with an orbital agitator and horizontal agitation. There was extract evaporation loss with air giving a $\% \mathrm{R}<70 \%$, on the other hand, none with nitrogen $(\% \mathrm{R}>90 \%)$. In extract purification with a $100 \mathrm{mg}$ silica cartridge, there was no lolitrem-B recovery, but with $500 \mathrm{mg}$ cartridges mean $\% \mathrm{R}$ was $92.7 \%$ with a 1.96 coefficient of variation (CV).
To decrease costs, tests were done with manually prepared columns for extract purification giving the following results: recovery $<70 \%$ and very variable with $200 \mathrm{mg}$ silica gel columns; $100.2 \%$ recovery with a 1.8 CV with $300 \mathrm{mg}$ silica gel columns, and $101.2 \%$ recovery and $1.4 \mathrm{CV}$ with $500 \mathrm{mg}$ columns. Since there was no significant difference according to the Student's t-test ( $\mathrm{p} \leq$ 0.05 ) between the 300 and $500 \mathrm{mg}$ columns, and for cost reasons, we opted for the method with $300 \mathrm{mg}$ silica gel columns. One of the precautions that must be taken when preparing the columns is to not compact them too much since this decreases toxin recovery.

The calibration curve in the 0.01 to $0.2 \mathrm{ng}$ range of lolitrem-B concentration in $20 \mu \mathrm{L}$ injection was adjusted to a linear model $(y=94.924 \mathrm{x}+1.3873)$, giving a coefficient of determination $\left(\mathrm{R}^{2}\right)$ equal to 0.9995 .

Table 1 shows the $\% \mathrm{R}$ for the different levels of lolitrem-B addition to perennial ryegrass samples without endophyte and the CV obtained at each level.

The highest CV (5.9\%) was obtained with the lowest addition of standard, $0.05 \mathrm{mg} \mathrm{kg}^{-1}$, considering this addition as the real quantification limit, and the lowest $\mathrm{CV}(0.9 \%)$ was obtained with the greatest addition, maintaining a high mean recovery percentage (99.1\%). Gallagher et al. (1985) obtained a \%R between 93 and 97\%, and Barker et al. (1993) reported a mean \%R of $90 \%$; on the other hand, this method obtained values between 96.6 and $100 \%$.

The time required per sample in HPLC with the established conditions was $5 \mathrm{~min}$, unlike the method used by Hovermale and Craig (2001) in which the time cycle between injections was $24 \mathrm{~min}$.

Figure 1 shows the chromatographs obtained for a perennial ryegrass sample without endophyte, the lolitrem-B comparative standard and the perennial ryegrass sample without endophyte but fortified with 0.6 mg kg-1 lolitrem-B.

The extraction, purification, and quantification method used allowed determining lolitrem-B in perennial ryegrass samples with no interference. The linear range in which lolitrem-B can be determined in the perennial ryegrass samples was from 0.05 to $2.0 \mathrm{mg} \mathrm{kg}^{-1}$.

Table 1. Recovery and coefficient of variation of lolitrem-B standard at different addition levels.

\begin{tabular}{|c|c|c|c|c|}
\hline $\begin{array}{l}\text { Addition } \\
\text { level }\end{array}$ & $\begin{array}{l}\text { Number of } \\
\text { replicates }\end{array}$ & $\begin{array}{c}\text { Recovery } \\
\text { mean }\end{array}$ & \multicolumn{2}{|c|}{$\begin{array}{c}\text { Coefficient } \\
\text { of variation }\end{array}$} \\
\hline $\mathrm{mg} \mathrm{kg}^{-1}$ & & . & \multirow[t]{6}{*}{$\%$} & \\
\hline 0.05 & 5 & 96.6 & & 5.9 \\
\hline 0.10 & 5 & 98.4 & & 2.8 \\
\hline 0.30 & 5 & 100.0 & & 1.5 \\
\hline 0.60 & 5 & 97.4 & & 3.1 \\
\hline 1.00 & 5 & 99.1 & & 0.9 \\
\hline
\end{tabular}



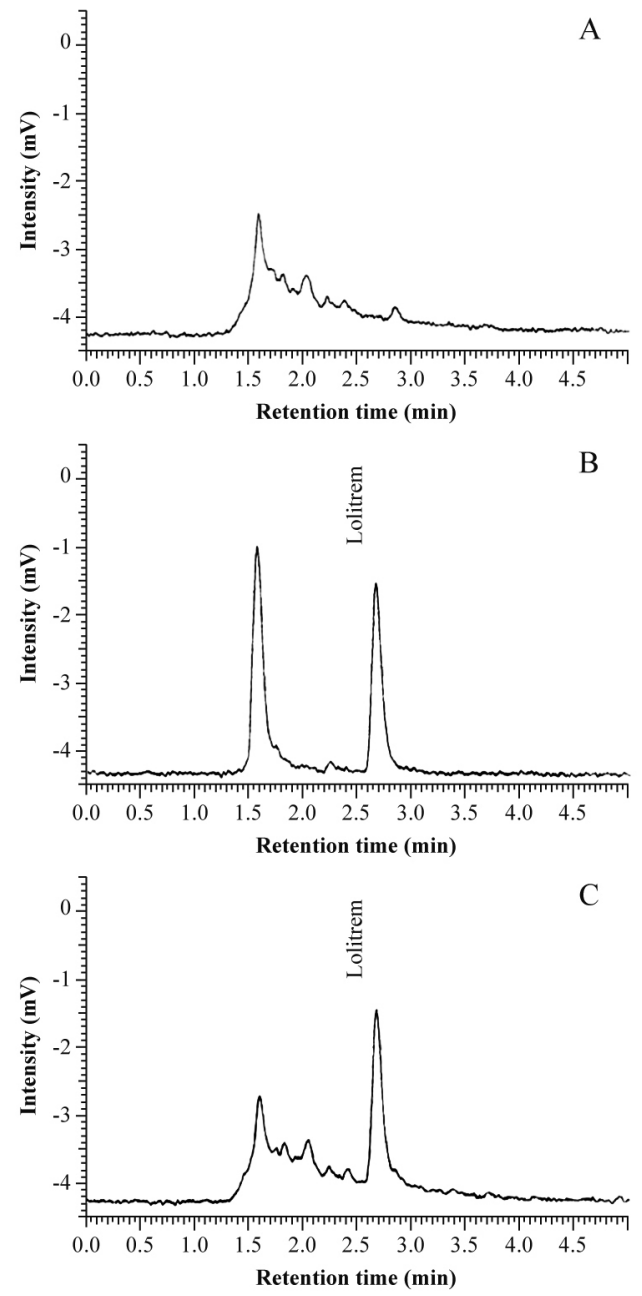

Figure 1. Chromatographs, $20 \mu \mathrm{L}$ of: (A) perennial ryegrass sample without endophyte, (B) lolitrem-B standard (3.1 pg $\left.\mu \mathrm{L}^{-1}\right)$, and (C) fortified perennial ryegrass sample $\left(0.6 \mathrm{mg} \mathrm{kg}^{-1}\right)$.

\section{CONCLUSIONS}

For the first time in Chile, a method was developed to determine lolitrem-B in perennial ryegrass samples, showing a high recovery percentage and low coefficient of variation. Furthermore, since it is a micro-method, it has low solvent consumption leading to minor costs and decreased risk for both the operator and the environment.

\section{ACKNOWLEDGEMENTS}

The authors thank the Fondo de Desarrollo e Innovación (FDI) of CORFO for the financing of Project 99C5AT-19. Likewise, we wish to thank Neale Tower and Sara Finch of AgResearch Ruakura, New Zealand, for their support to acquire the lolitrem-B standard, and to Christian Hepp of INIA-Tamel Aike for facilitating contacts in New Zealand.

\section{RESUMEN}

Implementación de un método para la determinación de lolitrem-B en ballica (Lolium perenne L.) por cromatografía líquida (HPLC). El lolitrem-B es una sustancia neurotóxica causante del síndrome "ryegrass staggers" o temblor de las ballicas en bovinos, ovinos y equinos que consumen ballicas perennes (Lolium perenne L.) infectadas con el hongo endófito Neotyphodium lolii (Latch, Christensen y Samuels) Glenn, Bacon y Hanlin. Debido al creciente uso de praderas con estas especies en el sur de Chile, es necesario conocer el contenido de lolitrem-B para realizar un adecuado manejo del pastoreo y evitar la intoxicación de los animales. El objetivo de este estudio fue implementar un método para la determinación de lolitrem-B en ballicas. Para establecer el método se utilizaron muestras de ballica sin endófito que fueron liofilizadas y mantenidas en oscuridad a $-18^{\circ} \mathrm{C}$. Se adicionó estándar puro de lolitrem-B y la extracción de la toxina se hizo con una mezcla de cloroformo-metanol (2:1), purificándose el extracto en columnas de silicagel 60 , preparadas manualmente. Se estudiaron cinco niveles de adición de estándar, con cinco repeticiones por nivel $\left(0,05 ; 0,10 ; 0,30 ; 0,60\right.$ y $\left.1,00 \mathrm{mg} \mathrm{kg}^{-1}\right)$. El porcentaje de recuperación promedio fue de 96,6 a $99,9 \%$ y el coeficiente de variación $(\mathrm{CV})$ promedio varió entre 0,9 y $5,9 \%$. La cuantificación se hizo por cromatografía líquida de alta resolución (HPLC) y detección por fluorescencia. El límite de cuantificación fue de $0,05 \mathrm{mg} \mathrm{kg}^{-1}$. Este método, para la determinación de la neurotoxina lolitrem-B en muestras de ballica, fue implementado por primera vez en Chile. Es rápido y de bajo costo, presentando una buena precisión, exactitud y repetibilidad.

Palabras clave: micotoxina, neurotoxina, hongo endófito, Neotyphodium lolii.

\section{LITERATURE CITED}

Ball, O.J.-P., G.M. Barker, R.A. Prestidge, and J.M. Sprosen. 1997. Distribution and accumulation of the mycotoxin lolitrem-B in Neotyphodium lolii-infected perennial ryegrass. J. Chem. Ecol. 23:1435-1449.

Ball, O.J.-P., R.A. Prestidge, and J.M. Sprosen. 1995. Interrelationships between Acremonium lolii, peramine, and lolitrem-B in perennial ryegrass. Appl. Environ. Microbiol. 61:1527-1533. 
Barker, D.J., E. Davies, G.A. Lane, G.C. Latch, H.M. Nott, and B.A. Tapper. 1993. Effect of water deficit on alkaloid concentrations in perennial ryegrass endophyte associations. p. 67-70. In Hume, D.E., G.C. Latch, and H.S. Easton (eds.) Proceedings of the Second International Symposium on Acremonium/ Grass Interactions. AgResearch, Palmerston North, New Zealand.

Blood, D.C., O.M. Radostits, J.H. Arundel, y C.C. Gay. 1992. Medicina veterinaria: Libro texto de las enfermedades del ganado vacuno, ovino, porcino, caprino y equino. $7^{\mathrm{a}}$ ed. p. 1430-1434. Interamericana Mc Graw \& Hill, México.

Fletcher, L.R., G.A. Lane, D.B. Baird, and E. Davies. 2001. Seasonal variations of alkaloid concentrations in two perennial ryegrass B endophyte associations. p. 535-542. In Paul, V.H., and P.D. Dapprich (eds.) Proceedings of the 4th International Neotyphodium/ Grass Interactions Symposium, Soest, Germany.

Gallagher, R.T., A.D. Hawkes, and J.M. Stewart. 1985. Rapid determination of the neurotoxin lolitrem-B in perennial ryegrass by high performance liquid chromatography with fluorescence detection. J. Chromatogr. 321:217-226.

Gallagher, R.T., A.D. Hawkes, P.S. Steyn, and R. Vleggaar. 1984. Tremorgenic neurotoxins from perennial ryegrass causing ryegrass staggers disorder of livestock: Structure elucidation of lolitrem-B. J. Chem. Soc. Chem. Commun. 9:614-616.

Gallagher, R.T., E.P. White, and P.H. Mortimer. 1981. Ryegrass staggers: isolation of potent neurotoxins lolitrem A and lolitrem-B from staggers-producing pastures. N.Z. Vet. J. 29:189-190.

Grancher, D., P. Jaussaud, A. Durix, A. Berthod, B. Fenet, Y. Moulard, et al. 2004. Countercurrent chromatographic isolation of lolitrem-B from endophyte-infected ryegrass (Lolium perenne L.) seed. J. Cromatography A 1059(1-2):73-81.

Hovermale, J.T., and M.A. Craig. 2001. Correlation of ergovaline and lolitrem-B levels in endophyteinfected perennial ryegrass (Lolium perenne). J. Vet. Diagn. Invest. 13:323-327.

Keogh, R.G., and B.A. Tapper. 1993. Acremonium lolii, lolitrem-B, and peramine concentrations within vegetative tillers of perennial ryegrass. p. 81-85. In Hume, D.E., G.C.M. Latch, and H.S. Easton (eds.) Proceedings of the Second International Symposium on Acremonium/Grass Interactions. AgResearch, Palmerston North, New Zealand.
Keogh, R.G., B.A. Tapper, and R.H. Fletcher. 1996. Distributions of the fungal endophyte Acremonium lolii, and of the alkaloids lolitrem-B and peramine, within perennial ryegrass. N.Z. Agric. Res. 39:121-127.

Lane, G.A., B.A. Tapper, E. Davies, D.E. Hume, G.C.M. Latch, D.J. Barker, et al. 1997. Effect of growth conditions on alkaloid concentration in perennial ryegrass naturally infected with endophyte. p. 179182. In Bacon, C.W., and N.S. Hill (eds.) Proceeding of $3^{\text {rd }}$ International Symposium on Neotyphodium/ Grass Interactions. Plenum Press, New York, USA.

Lanuza, F., A. Torres, y E. Cisternas. 2003a. Antecedentes generales del complejo Listronotus bonariensisAcremonium lolii en la producción bovina. In Lanuza, F., A. Torres, y E. Cisternas (eds.) El gorgojo y el endófito de las ryegrass en la producción de leche y carne en el sur de Chile. Boletín INIA No 100. p. 9-16. Instituto de Investigaciones Agropecuarias, Centro Regional de Investigación Remehue, Osorno, Chile.

Lanuza, F., H. Uribe, O. Araya, F. Wittwer, A Torres, E. Cisternas, et al. 2003b. Efecto del consumo de ryegrass con endófito $(N$. lolii) sobre la producción de leche y carne bovina. In Lanuza, F., A. Torres, y E. Cisternas (eds.) El gorgojo y el endófito de las ryegrass en la producción de leche y carne en el sur de Chile. Boletín INIA No 100. p. 89-124. Instituto de Investigaciones Agropecuarias, Centro Regional de Investigación Remehue, Osorno, Chile.

Miles, C.O., S.C. Munday, A.L. Wilkins, R.M. Ede, and N.R. Towers. 1994. Large-scale isolation of lolitrem-B and structure determination of lolitrem E. J. Agric. Food Chem. 42:1488-1492.

Oldenburg, E. 1997. Endophytic fungi and alkaloid production in perennial ryegrass in Germany. Grass Forage Sci. 52:425-431.

Porter, J.K. 1995. Analysis of endophyte toxins: fescue and other grasses toxic to livestock. J. Anim. Sci. 73:871-880.

Rowan, D. 1993. Lolitrems, peramine and paxilline: mycotoxins of the ryegrass/endophyte interaction. Agric. Ecosyst. Environ. 44:103-122.

Siegel, M.R., G.C.M. Latch, L.P. Bush, F.F. Fannin, D.D. Rowan, B.A. Tapper, et al. 1990. Fungal endophyteinfected grasses: alkaloid accumulation and aphid response. J. Chem. Ecol. 16:3301-3315.

Siegel, M.R., G.C.M. Latch, and M.C. Johnson. 1987. Fungal endophytes of grasses. Ann. Rev. Phytopathol. 25:293-315. 